DOI 10.1590/S0104-64972015002322

\title{
A proposal to synonymize the freshwater crab Hypolobocera olgaluciae Ramos-Tafur and Ríos, 2007 with Hypolobocera buenaventurensis (Rathbun, 1905) from Colombia (Crustacea: Decapoda: Pseudothelphusidae)
}

\author{
Ada Acevedo and Martha R. Campos
}

(AA) Universidad Nacional de Colombia, Departamento de Biología, Ciudad Universitaria, Cra 30, calle 45, Bogotá D.C., Colombia. E-mail: adacevedoal@unal.edu.co

(MRC) Universidad Nacional de Colombia, Instituto de Ciencias Naturales, Ciudad Universitaria, Cra 30, calle 45, Bogotá D.C., Colombia. E-mail: mhrochad@unal.edu.co

\begin{abstract}
Hypolobocera olgaluciae Ramos-Tafur and Ríos, 2007 is considered herein as junior synonym of $H$. buenaventurensis (Rathbun, 1905) taking into account that the morphological differences on the first male gonopod are not significant and are the consequence of natural variations of the populations. The first male gonopod of $H$. buenaventurensis is redescribed and illustrated.
\end{abstract}

Key words: Brachyura, Neotropical region, Taxonomy, junior synonym.

\section{INTRODUCTION}

The morphological characters of the first male gonopod are essential for the taxonomic determination of the species of freshwater crabs (Smalley, 1964). This specificity is due to the fact that the gonopod and the female opening form a lock/key system with the function of transferring the sperm to the female.

Each genus is characterized by a general pattern associated to the first male gonopod: presence and shape of the lateral lobe, accessory lobe, mesial lobe, processes, and projections. All species of a genus share the general pattern, but each species is distinguished by a set of specific morphological characters; they determine the identity of the species and allow its differentiation with respect to the other species of the genus. In general, for a given species there are different populations and the specific environmental conditions can induce small changes in the morphological characters but the identity of the species is held (Rodriguez, 1982).

Some examples described in the literature serve to illustrate the previously mentioned fact: (A) In the revision of the genus Neostrengeria Pretzmann, 1965, the author describes morphological variations of the first male gonopod of some species, particularly on the lateral lobe, the accessory lobe, the apex outline and the meso-caudal projection of the spermatic channel, which are due to populational variations (Campos, 1994). (B) In the case of the genus Hypolobocera Ortmann, 1897, the variations appear on the lateral lobe and the apex outline (Campos, 2003: Figs. 5A, B; 17E, F). (C) Campos and Guerra (2008) synonymized the freshwater crab species Hypolobocera solimani Ramos-Tafur, 2006 with Hypolobocera alata Campos, 1989, and Hypolobocera triangula Ramos-Tafur, 2006 with Hypolobocera rotundilobata Rodríguez, 1994, because the morphological differences represent natural variations within the populations.

Ramos-Tafur and Ríos (2007) described a new species of freshwater crab of western Colombia: Hypolobocera olgaluciae Ramos-Tafur and Ríos, 2007. After the taxonomic identification of the species based on the morphology of the first male gonopod, the authors concluded that the new species was closely related to Hypolobocera buenaventurensis (Rathbun, 1905).

In the present work, after comparing the holotype of $H$. olgaluciae with material of $H$. buenaventurensis 
from the Marine Biology Collection, Universidad del Valle (CRBMUV), Cali, Colombia, we concluded that the morphological differences of the first male gonopod correspond to populational variations of the species. Accordingly, here we propose $H$. olgaluciae as junior synonym of $H$. buenaventurensis.

The terminology used for the different processes of the gonopod follows Smalley (1964) and Campos (2005; 2014). The material examined is deposited in the Marine Biology Collection, Universidad del Valle (CRBMUV) and in the collection of the Instituto de Ciencias Naturales, Universidad Nacional de Colombia, Bogotá, Colombia (ICNMHN-CR). The following abbreviations are used: carapace breadth (cb), which is measured across the carapace at its widest point; carapace length (cl), measured along the midline, from the frontal to the posterior margin.

\section{Systematics}

\section{Family Pseudothelphusidae Ortmann, 1893}

\section{Tribe Hypolobocerini Pretzmann, 1971}

\section{Genus Hypolobocera Ortmann, 1897}

\section{Hypolobocera buenaventurensis (Rathbun, 1905)}

Pseudothelphusa buenaventurensis Rathbun, 1905: 307, Fig. 98.- Coifmann, 1939: 107.Pretzmann, 1965: 10.

Hypolobocera (Hypolobocera) buenaventurensisPretzmann, 1971: 17.- Pretzmann, 1972: 48-49.

Hypolobocera buenaventurensis- Rodriguez, 1982: 190.- Prahl, 1985: 44.- Prahl, 1987: 59-64, Figs. 1a-c, 2a.- Prahl, 1988: 171-172.-Campos, 2003: 771.- Ramos-Tafur and Ríos, 2007: 42, Fig. 3A-D.- Campos, 2005: 258, Fig. 75.- Campos, 2014: 340, Figs. 116-117.

Hypolobocera olgaluciae Ramos-Tafur and Ríos, 2007: 39-45, Figs. 1A-E, 2A-D.

Material examined. Colombia. Valle del Cauca: Buenaventura, Bajo Anchicayá, 1 Oct 1983, the male carapace was fragmented, in the jar there was only the left first male gonopod, CRBMUV 83076.- Bajo Calima, 8 Apr 1987, 1 female, cl $38.86 \mathrm{~mm}$, cb $59.80 \mathrm{~mm}$, CRBMUV 87017.Anchicayá River, 1 Mar 1979, 4 females, the largest cl $24.92 \mathrm{~mm}$, cb $39.42 \mathrm{~mm}$, the smallest cl 21.28 mm, cb 13.94 mm, CRBMUV 79083.- Vereda Bendiciones, 7 Feb 1984, 1 male juvenile, cl 20.42 mm, cb 32.60 mm, CRBMUV 84081.- Calima, Chancos River, Afluent of Calima River, 23 May 1993, leg. G. Acevedo, 1 male holotype of $H$. olgaluciae, cl $23.70 \mathrm{~mm}$, cb $37.76 \mathrm{~mm}, 1$ female paratype of $H$. olgaluciae, cl $22.38 \mathrm{~mm}$, cb 35.06 mm, CRBMUV 93001.- Restrepo, Vereda Alegre, Campo Chanco, Calima River, 435 m alt., 25 May 1983, leg. J. D. Lynch, 1 female, cl $35.40 \mathrm{~mm}$, cb $56.60 \mathrm{~mm}$, ICN-MHN-CR 0452.- Vereda Alegre, Campo Vegas, Calima River, $200 \mathrm{~m}$ alt., 1 Jun 1983, leg. J. D. Lynch, 1 female, cl 23.30 mm, cb 35.90 mm, ICN-MHN-CR 0453.--Vereda Alegre, Campo Chanco, Calima River, $435 \mathrm{~m}$ alt., 3 Jun 1983, leg. J. D. Lynch, 2 females, cl 36.20 and $20.42 \mathrm{~mm}$, cb 59.46 and $32.60 \mathrm{~mm}, \mathrm{ICN}$ MHN-CR 0454, 0455.

Redescription of the male first gonopod and third maxilliped. First male gonopod bent caudocephalically; mesial side almost straight; lateral side wide basally, border convex, wide middle depression; strong caudal ridge longitudinally, sinuous, ending in narrow ridge beyond lateral lobe; caudal margin sinuous, ending rounded distally and forming rounded lobe basally with conspicuous setae; lateral lobe nearly semicircular with crenulations on distal border; cephalic surface with two crests, the first one is transverse on distal half, the second one is parallel to lateral lobe and ends some distance from distal border of lateral lobe; apex outline is oval in distal view, with a prominent papilla on cephalic border and a rounded papilla near spermatic channel; mesial lobe subtriangular; mesocaudal projection of spermatic channel terminated into rounded papilla; spermatic channel with irregular rows of spinules (Fig. 1A-E). Third maxilliped with exognath 0.3 to 0.4 the length of ischium of endognath (Fig. 1F).

Remarks. Recently, the first author revised 

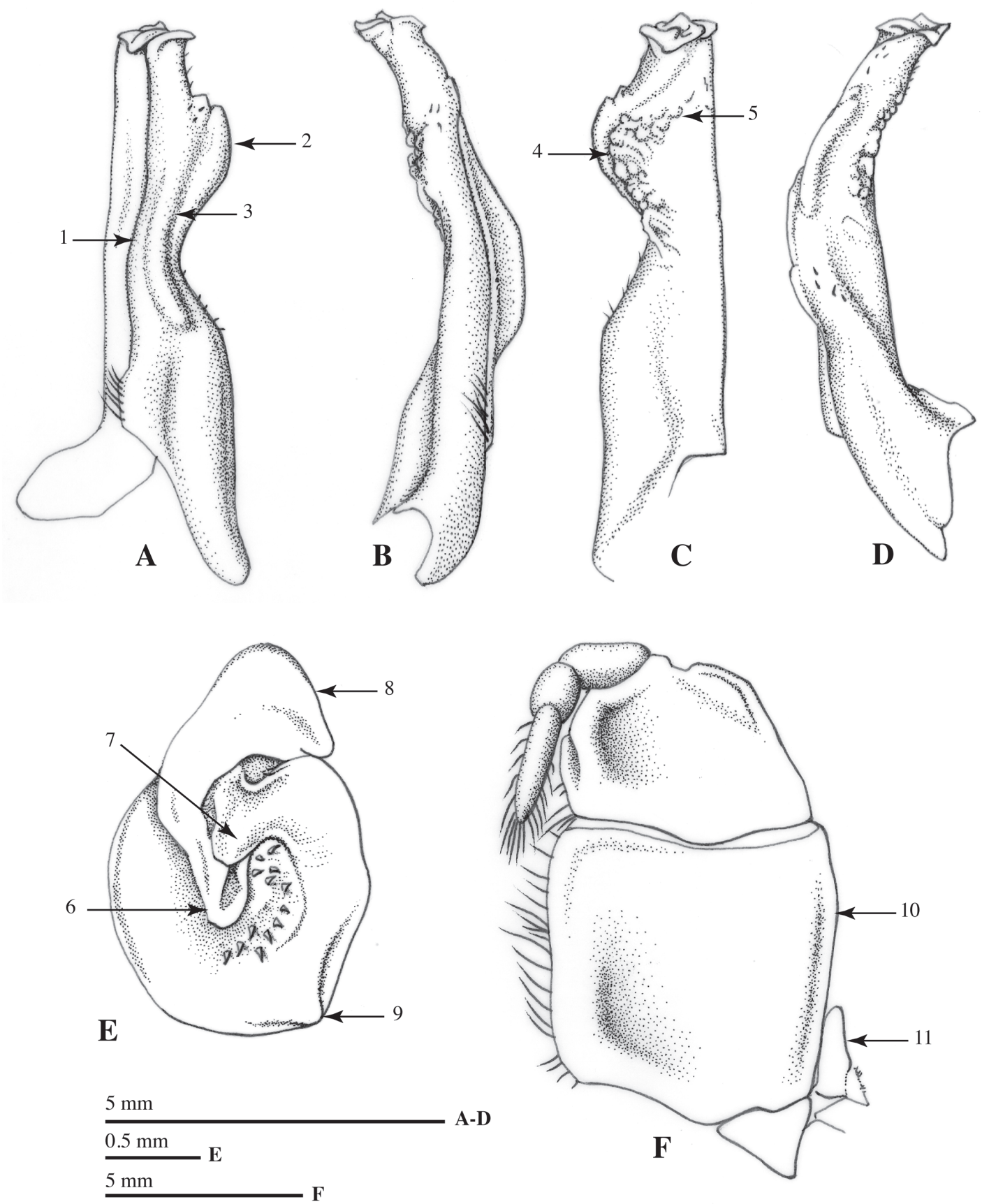

Figure 1. Hypolobocera buenaventurensis (Rathbun, 1905), male, CRBMUV 83076. A, left first gonopod, caudal view; B, same, mesial view; $\mathrm{C}$, same, cephalic view; D, same, lateral view; E, apex distal view; F, left third maxilliped, external view. 1, caudal margin; 2, lateral lobe; 3 , caudal ridge; 4 , tuberculated crest; 5 , transverse crest; 6 , mesocaudal projection of spermatic channel; 7, central papilla; 8, mesial lobe; 9 , cephalic papilla; 10, ischium of endognath; 11, exognath of third maxilliped.

the CRBMUV collection and she found a male specimen of Hypolobocera buenaventurensis from Buenaventura, Bajo Anchicayá, Valle del Cauca, under the number CRBMUV 83076. Unfortunately, the carapace of this specimen was fragmented, and in the jar there was only available the left first male gonopod, which is illustrated in the present contribution (Fig. 1A-F). In addition, she also found the holotype of the species Hypolobocera olgaluciae. The left first gonopod was not found in the jar, but the right first gonopod was attached to the crab and it is herein illustrated (Fig. 2A-F).

When the first male gonopod of $H$. buenaventurensis (Fig. 1A-E) was compared with 

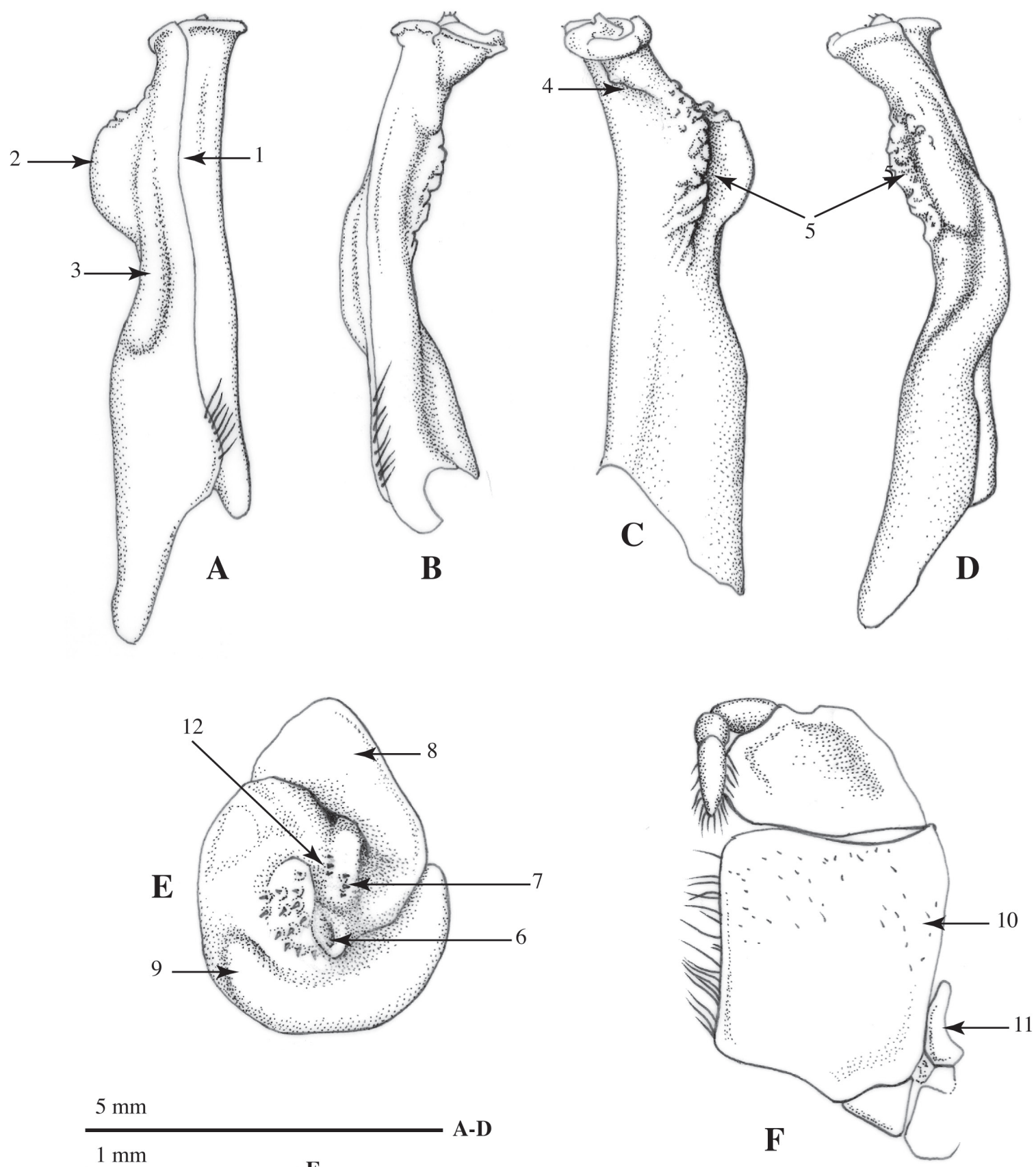

$5 \mathrm{~mm}$

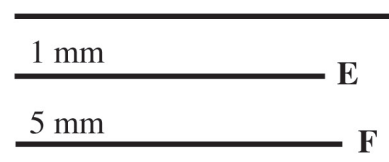

A-D

Figure 2. Hypolobocera olgaluciae Ramos-Tafur and Ríos, 2007, male holotype, CRBMUV 93001. A, right first gonopod, caudal view; B, same, mesial view; C, same, cephalic view; D, same, lateral view; E, apex distal view, F, left third maxilliped, external view. 1, caudal margin; 2 , lateral lobe; 3 , caudal ridge; 4, tuberculated crest; 5 , transverse ridge; 6 , mesocaudal projection of spermatic channel; 7 , central papilla; 8, mesial lobe; 9, cephalic papilla; 10, ischium of endognath; 11, exognath of third maxilliped; 12, spinules.

the one of $H$. olgaluciae (Fig. 2A-E), we found that most of the morphological features of both species overlap. However, there are some differences. a) the lateral lobe of both species is nearly semicircular, with crenulations on distal border; however, it is wider in $H$. olgaluciae than in $H$. buenaventurensis; b) both species present a prominent tuberculated crest, parallel to lateral lobe on the cephalic surface; however, in $H$. buenaventurensis the crest ends at some distance of the distal border of lateral lobe, whereas in $H$. olgaluciae it goes beyond the distal border of the lateral lobe; c) $H$. buenaventurensis exhibits a transverse tuberculated crest on the subdistal half of the cephalic surface; meanwhile, 
H. olgaluciae shows a transverse ridge, instead of the tuberculated crest; d) the mesial lobe of both species is subtriangular in distal view; however, in $H$. buenaventurensis the external border is smooth, whereas in H. olgaluciae it is nearly sinuous; e) the mesocaudal projection of spermatic channel in $H$. buenaventurensis ends into rounded papilla without spinules on its base, meanwhile in $H$. olgaluciae it is semi-acute with 3 spinules on its base.

The morphological differences described above for the first male gonopod correspond to populational variations of the species, which do not alter the overall pattern of $H$. buenaventurensis. Likewise, the additional morphological characters of the carapace and third maxilliped (see Figs. 1F, 2F) are similar for both species. In conclusion, $H$. olgaluciae should be considered as a junior synonym of $H$. buenaventurensis.

\section{ACKNOWLEDGEMENTS}

The authors are grateful to Dr. Jaime Cantera for authorizing the visit of the first author to the collection of Marine Biology, Universidad del Valle (CRBMUV). The illustrations were prepared by Domingo Vega.

\section{REFERENCES}

Campos, M.R. 1989. Nuevas especies de cangrejos de agua dulce del género Hypolobocera (Crustacea: Decapoda: Pseudothelphusidae) para Colombia. Trianea, 3: 143-147.

Campos, M.R. 1994. Diversidad en Colombia de los cangrejos del género Neostrengeria. Academia Colombiana de Ciencias Exactas Físicas y Naturales. Col. Jorge Álvarez Lleras, 5: $1-143$.

Campos, M.R. 2003. A review of the freshwater crabs of the genus Hypolobocera Ortmann, 1897, from Colombia (Crustacea: Decapoda: Brachyura: Pseudothelphusidae). Proceedings of the Biological Society of Washington, 116(3): 754-802.

Campos, M.R. 2005. Freshwater crabs from Colombia. A taxonomic and distributional study. Academia Colombiana de Ciencias Exactas Físicas y Naturales. Col. Jorge Álvarez Lleras, 24: 1-363.

Campos, M.R. 2014. Crustáceos decápodos de agua dulce de Colombia. Biblioteca José Jerónimo Triana, 27: 1-691.

Campos, M.R. and Guerra, L.A. 2008. Propuesta de sinonimia para las especies de cangrejo dulceacuícola Hypolobocera solimani e Hypolobocera triangula de Colombia. Revista de Biología Tropical, 56(3): 987-994
Coifmann, I. 1939. Potamonidi della Guiana Inglese raccolti dal Prof. Nello Beccari. Archivio Zologico Italiano, 27: 93-116.

Ortmann, A. 1893. Die Dekapoden-Krebse des Strassbourg Museums, mit besonder berücksichtigung der von Herrn Dr. Döderlein bei Japan und bei den Liu-Kiu-Inseln gesammelten und zur Zeit im Strassburger Museum aufbewahrten Formen. VII Theil Abtheilung: Brachyura (Brachyura genuina Boas) II. Unterabtheilung: Cancroidea, 2 Section: Cancrinea, 1. Gruppe: Cyclometopa. Zoologische Jahrberichter, 7: 411-495.

Ortmann, A. 1897. Carcinologische Studien. Zoologische Jahrbücher, Abteilung für Systematik, Geographie and Biologie der Tiere, 10: 258-372.

Prahl, H. von 1985. Distribución del cangrejo de agua dulce Hypolobocera beieri Pretzmann, 1968 y anatomía de su gonópodo. Actualidades Biológicas, 14(52): 43-47.

Prahl, H. von 1987. Redescripción de Hypolobocera buenaventurensis, un cangrejo de agua dulce (Decapoda: Pseudothelphusidae) del Pacífico Colombiano. Boletín Ecotrópica, 16: 59-64.

Prahl, H. von 1988. Fresh-water crabs (Crustacea: Decapoda: Pseudothelphusidae) of the Pacific Drainage of Colombia. Zoologische Jahrbücher für Systematik, 115: 171-186.

Pretzmann, G. 1965. Vorläufiger Bericht über die Familie Pseudothelphusidae. Anzeiger der Österreichischen Akademie der Wissenschaften Mathematische Naturwissenschaftliche Klasse, (1) 1: 1-10.

Pretzmann, G. 1971. Fortschritte in der Klassifizierung der Pseudothelphusidae. Anzeiger der Mathematisch Naturwissenschaftliche der Österreichischen Akademie der Wissenschaften, (1)179(1-4): 14-24.

Pretzmann, G. 1972. Die Pseudothelphusidae (Crustacea Brachyura). Zoologica, 42(120) pt. 1: 1-182.

Ramos-Tafur, G. 2006. Dos nuevas especies de cangrejos de agua dulce (Brachyura: Pseudothelphusidae) de la Serranía de Los Paraguas, Cordillera Occidental de Colombia. Revista de Biología Tropical, 54(3): 1047-1056.

Ramos-Tafur, G. and Ríos, R. 2007. Hypolobocera olgaluciae, una nueva especie de cangrejo de agua dulce (Brachyura, Pseudothelphusidae) del río Chancos, departamento del Valle del Cauca, Colombia. Contribuciones al Estudio de los Crustáceos del Pacífico Este, 4(2): 39-45.

Rathbun, M.J. 1905. Les crabes d'eau douce (Potamonidae). Nouvelles Archives du Muséum d'Histoire Naturelle Paris, 7(4): 159-321, pls. 11-22.

Rodriguez, G. 1982. Les crabes d'eau douce d'Amérique. Famille des Pseudothelphusidae. Paris, ORSTOM, 223p. (Faune Tropicale 22).

Rodríguez, G. 1994. A revision of the type material of some species of Hypolobocera and Ptychophallus (Crustacea: Decapoda: Pseudothelphusidae) in the National Museum of Natural History, Washington D. C., with descriptions of a new species and a new subspecies. Proceedings of the Biological Society of Washington, 107(2): 296-307.

Smalley, A. 1964. A terminology for the gonopods of the American River crabs. Systematic Zoology, 13(1): 28-31.

Submitted 6 August 2015

Accepted 19 September 2015 
